\title{
Advancement in Medical Sciences to Treat Medical and Surgical Diseases including Prevention, Treatment and Vaccine Development of COVID-19 in Pandemic
}

\author{
Ahsan Siddiqui, M.D, M.S.P.H (UK)* \\ Department of Quality Management \& Patient Safety, General Directorate of Health, Riyadh Saudi Arabia \\ *Corresponding author: Ahsan Ali Siddiqui, Consultant Epidemiologist, Quality Management \& Patient Safety, \\ Department, General Directorate of Health, Riyadh Saudi Arabia
}

\section{ARTICLE INFO}

Received: 㟵 June 25, 2020



Citation: Ahsan Ali Siddiqui. Advancement in Medical Sciences to Treat Medical and Surgical Diseases including Prevention, Treatment and Vaccine Development of COVID-19 in Pandemic. Biomed J Sci \& Tech Res 28(4)-2020. BJSTR. MS.ID.004695.

Keywords: Health Care Workers (HCW); Reverse Transcription-Polymerase Chain Reaction-RT-PCR, COVID-19 Novel Corona Virus; Detection; RT-LAMP; SARS-CoV-2; ELISA Immunoassays; Lateral Flow Assays; Quarantine; Social Distancing; Turkey; Antibodies; Glycans; Immunoglobulin M; Pneumonia; Prediction; Biliary Tract Carcinoma; Cholangiocarcinoma; Gallbladder Carcinoma; Molecular Genetics; Infodemic; Infodemiology

\section{ABSTRACI}

Background and Objective: The Aim of this research Article is to discuss and highlight the success of Latest Medical Science and Technology in the twenty first century as compare to old age. The result of Modern Medical Inventions and easy access to best health care services people are living longer and healthier.

Methods: The Author of this article has randomly selected 15 Articles from PUBMED, Other Different Medical Sciences Journals with the word using "Advancement in Medical Sciences to treat Medical and Surgical Diseases including Prevention, Treatment and Vaccine development of COVID-19". The Author relies on Conceptual Literature Review for the Methodology of this article. Where the groups of Articles are reviewed and analyzed to find out the answer of the Question "Study favors or Ignores Advancement in Medical Sciences to treat Medical and Surgical Diseases including Prevention, Treatment and Vaccine development of COVID-19". The Table 1 is created to Analyze the 15 randomly selected Articles and the results has been presented By SPSS software diagrammatic presentation.

Results: Author of this Article has used SPSS 19 Software to present the results of the reviewed Articles. First SPSS Diagram shows that All selected 15 Articles favors the Importance of role in Advancement in Medical Sciences to treat Medical and Surgical Diseases including Prevention, Treatment and Vaccine development of COVID-19. The Second SPSS Diagram shows that 15 Articles agreed 100\% for the Importance of Advancement in Medical Sciences to treat Medical and Surgical Diseases including Prevention, Treatment and Vaccine development of COVID-19.

Conclusion: Due to the Advancement in Medical Sciences and Medical Treatment, Inventions people are living longer and healthier than ever before. Nuclear Radiotherapy, Nuclear radiology, MRI Scan, CT Scan, X Rays, Ultrasound, Angioplasty and Angiography others made the diagnosing and treatment easier for the patients. Current COVID-19 Pandemic, MERS, SARS, EBOLA and other epidemics teaches us the lesson than as the world population grows, we need more research and technology to handle Pandemic such as COVID-19. More resources and advance technology are needed to battle diseases and training for medical staff is needed.

\section{Introduction}

Based on clinical features [1] pathology the pathogenesis of acute respiratory disorder induced by either highly homogenous coronaviruses or other pathogens the evidence suggests that excessive inflammation oxidation and an exaggerated immune response very likely contribute to COVID-19 pathology. This leads to a cytokine storm and subsequent progression to acute lung injury-ALI /acute respiratory distress syndrome-ARDS and often death. Melatonin a well-known anti-inflammatory and antioxidative molecule is protective against ALI/ARDS caused by viral and other pathogens. Melatonin is effective in critical care 
patients by reducing vessel permeability anxiety sedation use and improving sleeping quality which might also be beneficial for better clinical outcomes for COVID-19 patients. Notably melatonin has a high safety profile. There is significant data showing that melatonin limits virus-related [1] diseases and would also likely be beneficial in COVID-19 patients. As we all know that current [2] Pandemic of COVID-19 novel corona virus is deadly and without vaccine and proven Treatment. More than quarter million people recently has died and more than four million people suffering from COVID-19 all over the world till May 2020.

World health organization has issued the warning in December 2019 for the Novel corona virus in Wuhan China. Governments of the countries including most developed countries such as the USA, the UK and EU Countries act slowly with ignoring the facts about COVID-19 severity. The lesson learned from the Pandemic
COVID-19 is that our health systems and health agencies do not have abilities to save their citizens and they [2] have to work hard to improve their abilities to save their citizens (Figure 1). The SARS-CoV-2 a family member of beta [3] coronaviruses possesses single-stranded positive-sense RNA with typical structural proteins involving the envelope membrane nucleocapsid and spike proteins that are responsible for the viral infectivity and nonstructural proteins. The effectual host immune response including innate and adaptive immunity against SARS-Cov-2 seems crucial to control and resolve the viral infection. However, the severity and outcome of the COVID-19 might be associated with the excessive production of proinflammatory cytokines "cytokine storm" leading to an acute respiratory distress syndrome. Regretfully the exact pathophysiology and treatment especially for the severe COVID-19 is still uncertain.

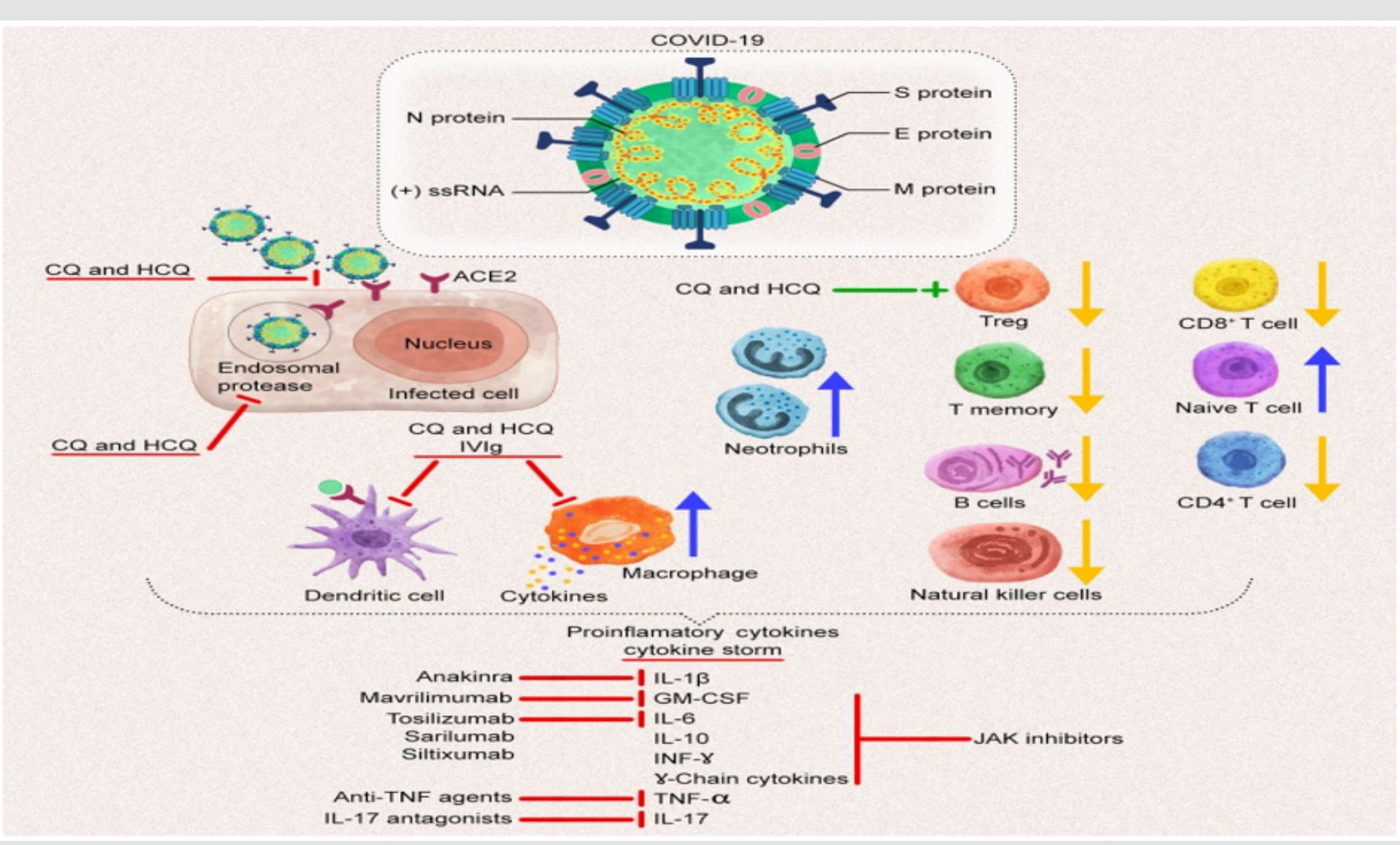

Figure 1: Abdurrahman Tufan, Aslihan Güler, Marco C (2020) [3].

The results of preliminary studies have shown that immune-modulatory or immune-suppressive treatments such as hydroxychloroquine interleukin IL-6 and IL-1 antagonists commonly [3] used in rheumatology, might be considered as treatment choices for COVID-19. Global Health and other organizations [4] such as WHO, UNHCR, UN, UNESCO, UNICEF did not act fast to Prevent and Control the COVID-19 Pandemic. Other Governments of the countries in the world act very slowly for the warnings given by WHO and other scientists. Later since November 2019 till now approximately 350,000 people have lost their lives due to COVID-19 and approximately 5 Million people are infected by this COVID-19 disease. Lessons should learn from COVID-19 Pandemic and it is not over yet as scientists predicts that COVID-19 is with us for next couple of years. The vaccine of COVID-19 is under development and there is not exact treatment [4] for COVID-19 by medical sciences till now [5] (Figure 2). 


\section{How does PCR testing for COVID-19 work?}

Polymerase chain reaction (PCR) testing can detect even very small amounts of viral genetic material in a sample by duplicating it many times over through a complex laboratory process called amplification.

(1) A test sample is swabbed from the back of the nose and processed to isolate genetic material.
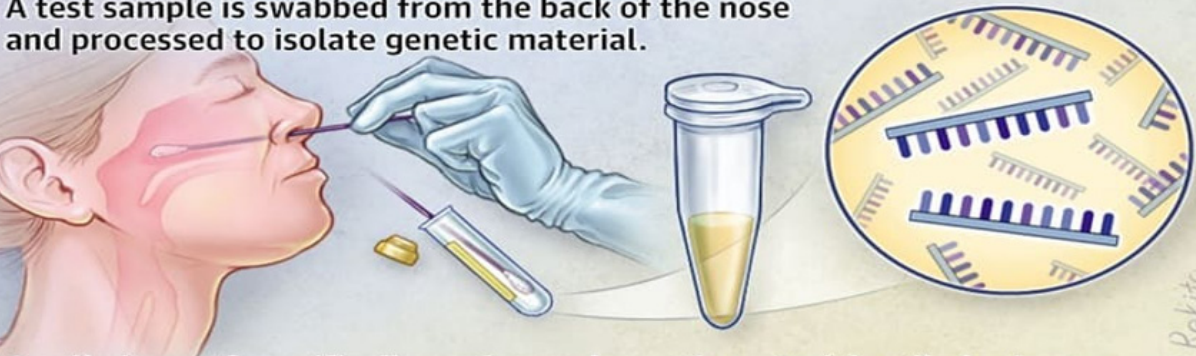

(2) Small pieces of specifically engineered genetic material, called primers, are introduced and bind to the isolated viral genetic material, initiating amplification.

Toणvण!!

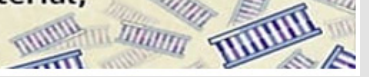

Figure 2: Google How does PCR Testing for COVID-19 work (2020) [5].

Currently there is not [6] any specific effective antiviral treatment for COVID-19. Despite the urgent need to find an effective antiviral treatment for COVID-19 through randomized controlled studies certain agents are being used all over the world based on either in-vitro or extrapolated evidence or observational studies. The most frequently used agents both in Turkey and all over the world including chloroquine hydroxychloroquine lopinavir/ritonavir favipiravir and remdesivir will be reviewed here. Nitazoxanide and ivermectin were also included in this review as they have recently been reported to have an activity against SARS-CoV-2 in vitro and are licensed for [6] the treatment of some other human infections.
While there is no vaccine [7] currently available for COVID-19 patients the treatment with Convalescent Plasma with other western medicines saves lives of hundreds of thousands of patients in COVID-19 Pandemic. There is need of more advance research and action to find out the Treatment of COVID-19 Pandemic. Global health including public health preventive medicine has failed the world in this current COVID-19 Pandemic when more than Quarter million people died all around the world and approximately 4.2 Million [7] people suffered from this deadly COVID-19 Pandemic [8] (Figure 3).



Figure 3: Google COVID-19 Cycle (2020) [8]. 
After seeing the Disaster resulting [9] from COVID-19 Pandemic in last five months all over the world where almost 370,000 people died and approximately 6 Million people are sick due to COVID-19. There is urgent need of VACCINE of COVID-19 Pandemic and there is news that may be Vaccine could be available in December 2020 or later. Although Developed [10] Countries such as USA, UK, France and countries of EU spends Billions of US Dollars on their Health System, but it did not stop the Deaths of COVID-19 Pandemic in their countries and they are actually affected the most in this world. The reason is, there is no current Vaccine, proven Treatment for COVID-19 to this date and still research is going on to [10] find the right Treatment or Vaccine for COVID-19. Current Pandemic of [11] COVID-19 has taught us that we in the twenty first century is not ready to provide health care to vulnerable community such as elders children and sick people with chronic illness. Such vulnerable people with bad health and low socio-economic status are more prone to get effected by COVID-19 novel corona virus. Upon reviewing the carefully [12] selected 8 News Articles only two articles provide the picture and documented evidence that may be accidentally in the Wuhan laboratory the studied novel corona virus got out of laboratory.

\section{Advancement in Medical Sciences to Treat Medical and Surgical Diseases}

Hypertension has been identified [13] as the leading global risk factor for mortality and as the third leading risk factor for disease burden. It is defined as a systolic blood pressure of $140 \mathrm{mmHg}$ or more or a diastolic blood pressure of $90 \mathrm{mmHg}$ or more or taking antihypertensive medication. Though it is known that nocturia is multifactorial, available literature does not relate elevated blood pressure level with increased urinary frequency and is scarce at best. A cross-sectional study was carried out in the OPD-Out Patient Department of a secondary care hospital of Karachi among patients with self-reported history of hypertension and on anti-hypertensive medication. The study findings revealed a significant positive association between both the elevated systolic and diastolic blood pressure levels and the [13] increased frequency of urination but after age and gender-based stratification [14] (Figure 4). Dengue is a viral illness that globally [15] affects around 50 million people annually and approximately 3.9 billion people are at risk to contract the infection. Liver is the major organ involved during the disease process. A randomized controlled trial was conducted Ziauddin hospital Clifton Karachi.
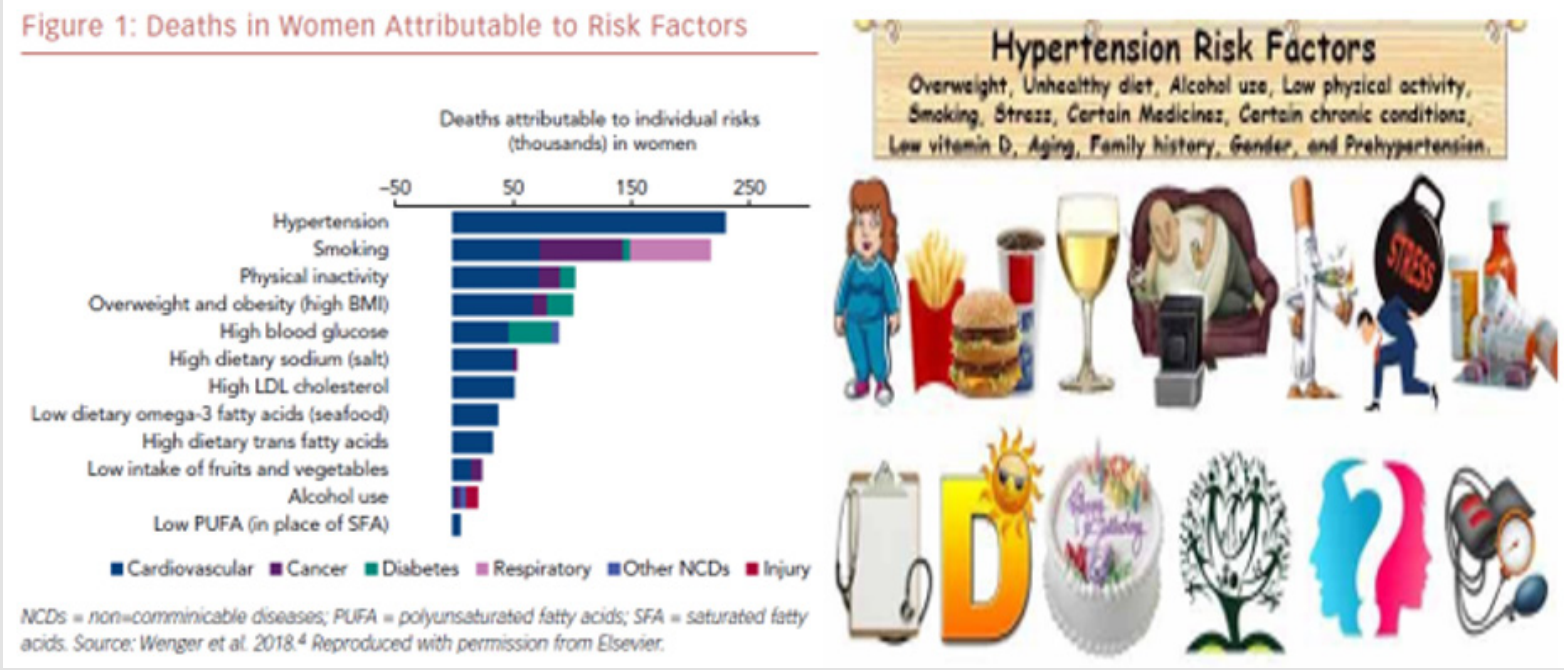

Figure 4: Google (2020) [14].

92 dengue patients were included in the study who were equally divided into two groups, A and B, which received silymarin and placebo respectively along with the symptomatic dengue treatment. The study showed no positivity in improvising liver function in the treatment group as determined by the serum levels of liver enzymes. Furthermore, symptomatologic improvement with the treatment of [15] Silymarin in dengue patients could not be established definitely. The global incidence of dengue [16] a mosquito-borne viral infection has grown dramatically in recent decades with about half of the world's population is now at risk. Its clinical manifestations include headache fever skinrashes leukopenia and arthralgia. A secondary data analysis of a randomized controlled trial on the effects of silymarin on hepatic enzymes and clinical manifestation of dengue was conducted. The clinical signs and symptoms of the dengue patients were recorded at the baseline before giving trial intervention. A significant association of rash and injected conjunctiva with gender of dengue patients and of nausea and vomiting headache retro-orbital pain and [16] injected conjunctiva with age of dengue patients was found [17] (Figure 5). 




Figure 5: Google Dengue Hemorrhagic fever (2020) [17].

\section{Methods}

The Author of this article has randomly selected 15 Articles from PUBMED, Other Different Medical Sciences Journals with the word using "Advancement in Medical Sciences to treat Medical and Surgical Diseases including Prevention, Treatment and Vaccine development of COVID-19". The Author relies on Conceptual Literature Review for the Methodology of this article. Where the groups of Articles are reviewed and analyzed to find out the

Table 1: 15 Selected Articles to show the Importance of role of "Advancement in Medical Sciences to treat Medical and Surgical Diseases including Prevention, Treatment and Vaccine development of COVID-19".

\begin{tabular}{|c|c|c|c|c|}
\hline S.NO & $\begin{array}{l}\text { Complete Reference of the Articles Selected for } \\
\text { Study }\end{array}$ & $\begin{array}{c}\text { Study Favors the } \\
\text { Importance of Role of } \\
\text { "Advancement in Medical } \\
\text { Sciences to Treat Medical } \\
\text { and Surgical Diseases } \\
\text { including Prevention, } \\
\text { Treatment and Vaccine } \\
\text { Development of COVID- } \\
\text { 19"-YES }\end{array}$ & $\begin{array}{c}\text { Study Ignores the } \\
\text { Importance of Role of } \\
\text { "Advancement in Medical } \\
\text { Sciences to Treat Medical } \\
\text { and Surgical Diseases } \\
\text { including Prevention, } \\
\text { Treatment and Vaccine } \\
\text { Development of COVID- } \\
19 \text { "-No }\end{array}$ & $\begin{array}{l}\text { Percentages\% of Articles } \\
\text { Agreed the Importance } \\
\text { of Role "Advancement in } \\
\text { Medical Sciences to Treat } \\
\text { Medical and Surgical } \\
\text { Diseases including } \\
\text { Prevention, Treatment } \\
\text { and Vaccine Development } \\
\text { of COVID-19". }\end{array}$ \\
\hline 1 & $\begin{array}{l}\text { Zhang R, Wang X, Ni L, Di X, Ma B, et al. (2020) } \\
\text { COVID-19: Melatonin as a Potential Adjuvant } \\
\text { Treatment. Life Sciences 250: } 117583 .\end{array}$ & YES & ------- & $100 \%$ \\
\hline 2 & $\begin{array}{l}\text { Abdurrahman Tufan, Aslihan Güler, Marco C } \\
\text { (2020) COVID-19, Immune System Response, } \\
\text { Hyperinflammation and Repurposing } \\
\text { Antirheumatic Drugs. Turkish Journal of Medical } \\
\text { Sciences 50(SI-1): 620-632. }\end{array}$ & YES & ------- & $100 \%$ \\
\hline 3 & $\begin{array}{l}\text { Serap Yavuz, Serhat Ünal (2020) Antiviral } \\
\text { Treatment of COVID-19. Turkish Journal of } \\
\text { Medical Sciences 50(SI-1): 611-619. }\end{array}$ & YES & ------- & $100 \%$ \\
\hline 4 & $\begin{array}{l}\text { Ahsan Ali Siddiqui (2020) The Need of Early } \\
\text { Detection of Positive COVID-19 Patients in the } \\
\text { Community by Viral Tests (e.g. RTPCR Tests) and } \\
\text { Antibody Tests (Serological Tests) to Stop the } \\
\text { Spread. AJBSR 9(1): 78-87. }\end{array}$ & YES & ------- & $100 \%$ \\
\hline 5 & $\begin{array}{l}\text { Ahsan Ali Siddiqui (2020) COVID-19 Pandemic } \\
\text { and Public health Preventions to Reduce the } \\
\text { Infection, Incidence and Distribution among the } \\
\text { Community. OAJBS 2(2): 345-352. }\end{array}$ & YES & ------ & $100 \%$ \\
\hline
\end{tabular}

answer of the Question "Study favors or Ignores Advancement in Medical Sciences to treat Medical and Surgical Diseases including Prevention, Treatment and Vaccine development of COVID-19". The Table 1 is created to Analyze the 15 randomly selected Articles and the results has been presented By SPSS software diagrammatic presentation (Table 1). Tuberculosis rates were declining [18] in Pakistan but several complex social and medical factors cause TB morbidity to increase. At present Pakistan ranked the sixth in WHO list of tuberculosis risk countries. 


\begin{tabular}{|c|c|c|c|c|}
\hline 6 & $\begin{array}{l}\text { Ahsan Ali Siddiqui (2020) Role of Convalescent } \\
\text { Plasma Therapy in Successful Prevention and } \\
\text { Treatment of Covid-19 Novel Corona Virus Critical } \\
\text { Patients, In } 2020 \text { Global Pandemic. Biomed J Sci \& } \\
\text { Tech Res 28(2): 21398-21407. }\end{array}$ & YES & ------- & $100 \%$ \\
\hline 7 & $\begin{array}{l}\text { Ahsan Ali Siddiqui (2020) The Urgent Need of } \\
\text { Reliable and Approved Vaccination for COVID-19 } \\
\text { Novel Corona Virus in Current Pandemic. Biomed J } \\
\text { Sci \& Tech Res 28(2): 21435-21443. }\end{array}$ & YES & ------ & $100 \%$ \\
\hline 8 & $\begin{array}{c}\text { Ahsan Ali Siddiqui (2020) The Recent } \\
\text { Management and Treatment of COVID-19 Novel } \\
\text { Corona Virus “Better use of Science, Better } \\
\text { Treatment for COVID-19 Patients". OAJBS 2(3): } \\
\text { 366-373. }\end{array}$ & YES & ------ & $100 \%$ \\
\hline 9 & $\begin{array}{l}\text { Ahsan Ali Siddiqui (2020) The Epidemiology of } \\
\text { COVID-19 Novel Corona Virus to Possibly Control } \\
\text { the Disease and Other Factors Relating to Health } \\
\text { Around the World. OAJBS 2(2):330-337. }\end{array}$ & YES & ------ & $100 \%$ \\
\hline 10 & $\begin{array}{l}\text { Ahsan Ali Siddiqui (2020) True or not? Chinese } \\
\text { government quotes WHO Chief statement "that } \\
\text { there is no Evidence that the New Coronavirus } \\
\text { Novel COVID } 19 \text { was Produced in the Laboratory" } \\
\text { But US Government Says, "that the Coronavirus } \\
\text { Originated from a Laboratory in China despite the } \\
\text { Lack of Evidence". Biomed J Sci \& Tech Res 27(5): } \\
\text { 21148-21155. }\end{array}$ & YES & ------ & $100 \%$ \\
\hline 11 & $\begin{array}{c}\text { Sarfraz Md, Shaikh S, Zaidi SA, Raees A, Siddiqui } \\
\text { AA, et al. (2018) Blood Pressure Levels and } \\
\text { Urinary Frequency in Hypertensive Patients: A } \\
\text { Cross-sectional Analysis. J Palliative Care Med 8: } \\
345 .\end{array}$ & YES & ------ & $100 \%$ \\
\hline 12 & $\begin{array}{l}\text { Momin A, Samina B, Uzma G, Ahsan Ali S, Hanieya } \\
\text { S, et al. (2018) Management of Dengue Infection; } \\
\text { a Prospective Study Highlighting the Effect of } \\
\text { Silymarin on Liver Functions Test. Palliative Med } \\
\text { Care 5(4): 1-7. }\end{array}$ & YES & ------ & $100 \%$ \\
\hline 13 & $\begin{array}{l}\text { Momin A, Anwar A, Imtiaz M, Mustafa N, Ahsan } \\
\text { Siddiqui, et al. (2019) Gender and age-based } \\
\text { evaluation of clinical signs and symptoms of } \\
\text { dengue: A secondary data analysis. SOJ Microbiol } \\
\text { Infect Dis 7(1): 1-4. }\end{array}$ & YES & ------ & $100 \%$ \\
\hline 14 & $\begin{array}{l}\text { Ahsan Ali S (2018) The Global Threat of Bird } \\
\text { (Avian) Flu its Treatment Methods and Public } \\
\text { Health Preventive Measures. SOJ Vet Sci 4(3): 1-4. }\end{array}$ & YES & ------ & $100 \%$ \\
\hline 15 & $\begin{array}{c}\text { Jamali Z, Siddiqui AA, Jamali D, Nazim S, Hasan S, } \\
\text { et al. (2018) Correlation of Early and Late Cord } \\
\text { Clamping Time with Hematological Variables: } \\
\text { An Observation Study Focusing on The Neonatal } \\
\text { Outcomes. SOJ Gynecology Obstetric Women's } \\
\text { Health 4(1): } 1-5 .\end{array}$ & YES & ------ & $100 \%$ \\
\hline
\end{tabular}

Recently the increased TB morbidity and mortality have placed additional pressure to act on state and local TB control programs which already had been substantially weakened by inadequate staffing and funding support. It's not easy to eliminate [19] T.B from the country with in few years because T.B is a communicable disease and it needs a lot of affective strategies for example health needs assessment, to change the model of the NTP, hard work good management and affective treatment to reduce [19] the incidence of T.B in Pakistan [20] (Figure 6). Literature Review was done carefully [21] for the Hot Current Topic Avian Flu and what are the Preventive Measures. Various Recommended and Good repute
Global Organizations such as WHO, CDC USA, BBC UK, NHS UK Others Literature was reviewed for Article writing and selecting Excellent Preventive Measures. This essay has explored the Avianbird flu in terms of definition, classification, signs and symptoms caused by Avian flu, statistics of morbidity and mortality caused by Avian flu in Turkey Thailand and other effected countries. In this essay I talk treatment health implications risks and the warnings about the Avian flu and food safety implications in humans to [21] prevent from the harmful effects of the Avian flu. Measure and statistical Analysis: IBM (2006) IBM SPSS Software USA [22] (SPSS Diagrams 1 \& 2). 


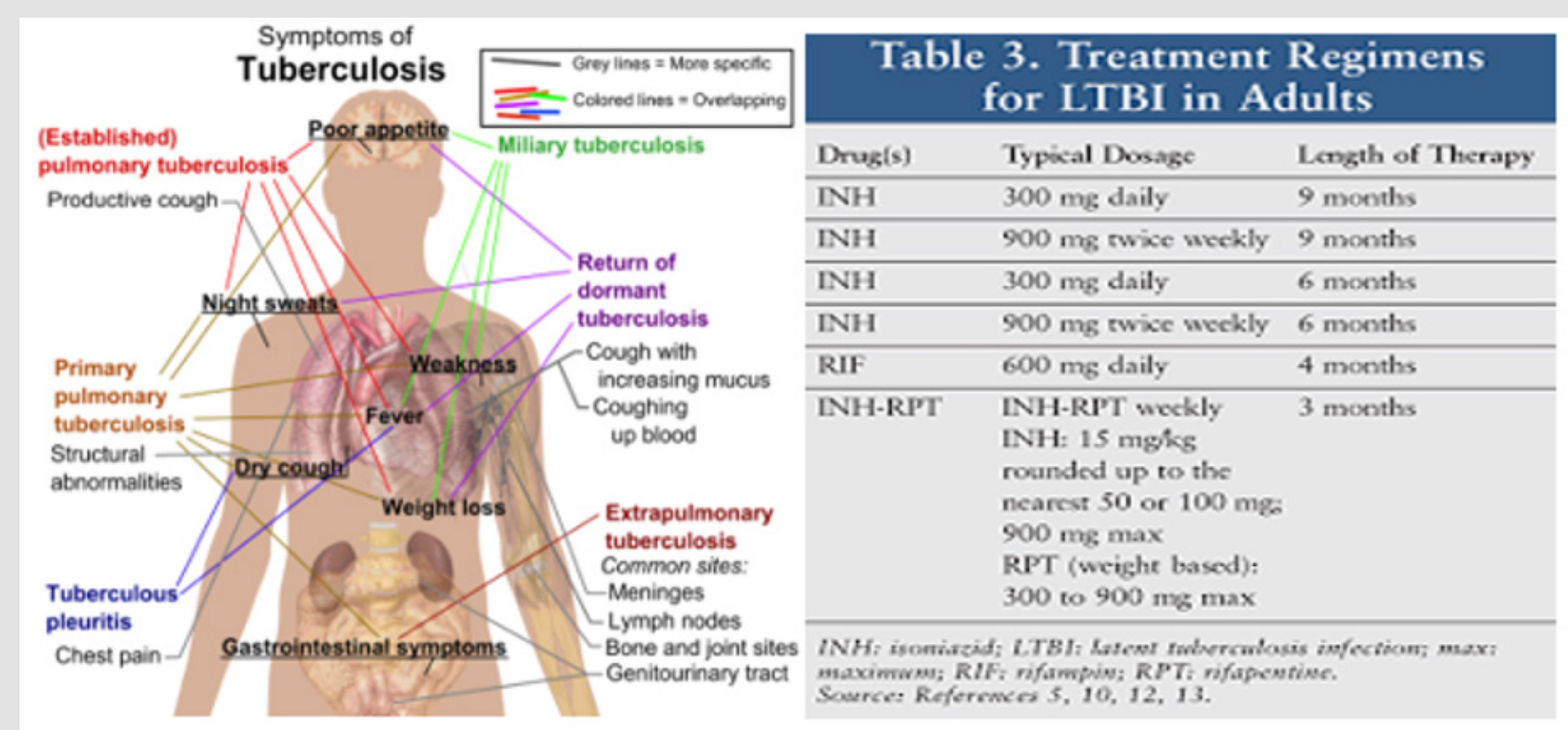

Figure 6: Google Tuberculosis (2020) [20].



SPSS Diagram 1. 


\section{Percentages\% of 15 Articles agreed the Importance of role "Advancement in Medical Sciences to treat Medical and Surgical Diseases including Prevention Treatment and Vaccine development of COVID-19".}

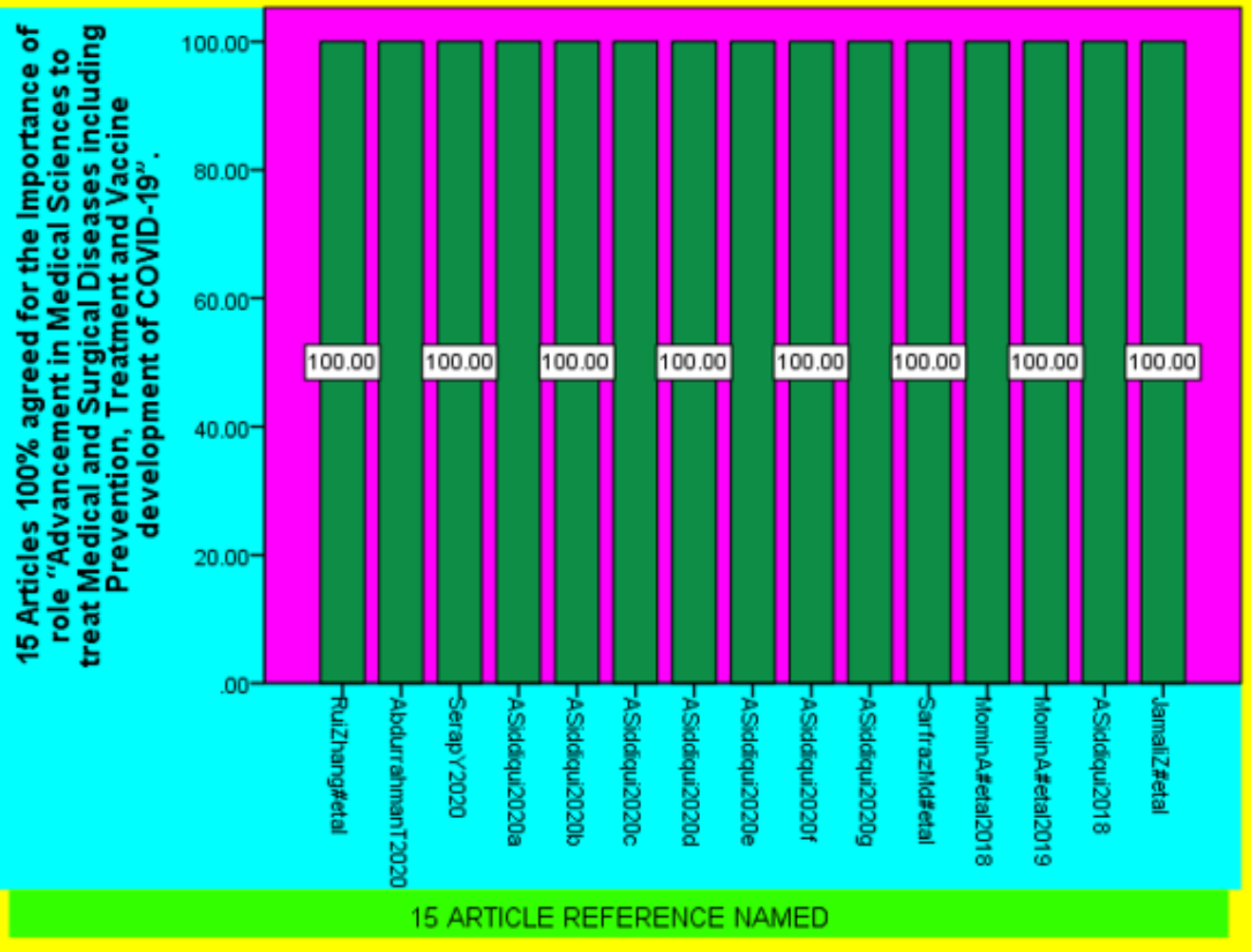

SPSS Diagram 2.

\section{Results}

Author of this Article has used SPSS 19 Software to present the results of the reviewed Articles. First SPSS Diagram shows that All selected 15 Articles favors the Importance of role in Advancement in Medical Sciences to treat Medical and Surgical Diseases including Prevention, Treatment and Vaccine development of COVID-19. The Second SPSS Diagram shows that 15 Articles agreed 100\% for the Importance of Advancement in Medical Sciences to treat Medical and Surgical Diseases including Prevention, Treatment and Vaccine development of COVID-19. The present study predicted [23] that no correlation in either group existed between hemoglobin, hematocrit and bilirubin with increasing cord clamping time. Furthermore, there was no association observed in neonates with anemia low hematocrit polycythemia and high bilirubin with increasing cord clamping time. Total of 340 pregnant women were incorporated in this study and their neonates were divided into two groups on the basis of cord clamping time.

Group 1 had clamping time of $45 \pm 7.92$ seconds and group 2 with clamping time of $118 \pm 33.26$ seconds. Hemoglobin was $13.29 \pm 1.33 \mathrm{mg} / \mathrm{dl}$ in group 1 and $13.43 \pm 1.06$ in group 2 . Hematocrit was $40.87 \pm 3.78 \%$ and $41.36 \pm 3.02 \%$ in group 1 and 2 respectively. Bilirubin $(\mathrm{mg} / \mathrm{dl})$ was $9.15 \pm 5.77$ in group 1 while $13.14 \pm 10.14$ in group 2. Anemia was present in $7.1 \%$ and $2.9 \%$ of infants in group 1 and respectively. Polycythemia was observed in $2.9 \%$ of infants of group 1 while $11.25 \%$ infants of group 2 presented with it. High bilirubin was seen [23] in 4.1\% and 19.4\% infants of group 1 and 2 respectively. The present study predicted [24] that considerable difference did not exist in various hematological parameters of male and female CML patients. However, there was significant difference observed in myelocyte count of these patients on the basis of gender. A total of 98 patients with 46 males and 52 females were included in the study having mean age of $40.24 \pm 11.63$ and $40.48 \pm 13.60$ respectively.

The mean \pm SD and median of variables was recorded in these two groups. Hemoglobin level (gm/dl) was $9.32 \pm 2.26$ and 9.20 in males while in females was $9.94 \pm 9.53$ and $8.45(\mathrm{p}=0.158)$, total leukocyte count $\left(\mathrm{x} 10^{3}\right.$ cells $\left./ \mathrm{mm}^{3}\right)$ was $232.10 \pm 166.88$ and 205.50 in males while $227.46 \pm 142.67$ and $223.50 \times 10^{3}$ cells $/ \mathrm{mm}^{3}$ in females $(\mathrm{p}=0.884)$, platelets $\left(\mathrm{x} 10^{3}\right.$ cells $\left./ \mathrm{mm}^{3}\right)$ in males was $455.14 \pm 354$ and 361.5 though in [24] females was $484 \pm 261.60$ and $481.50(\mathrm{p}=0.222)$. Cancer arises in the context [25] of an in vivo tumor microenvironment. This microenvironment is both a cause and consequence of tumorigenesis. Tumor and host cells coevolve dynamically through indirect and direct cellular interactions 
eliciting multiscale effects on many biological programs including cellular proliferation growth and metabolism as well as angiogenesis and hypoxia and innate and adaptive immunity. We describe how inhibition of targets such as cholesterol synthesis and metabolites reactive oxygen species and hypoxia macrophage activation and conversion indoleamine 2, 3-dioxygenase regulation of dendritic cells vascular endothelial growth factor regulation of angiogenesis fibrosis inhibition endoglin and Janus kinase signaling emerge as examples of important potential nexuses in the regulation of [25] tumorigenesis and the tumor microenvironment that can be targeted.

\section{Discussion}

This was an observational study [26] conducted in the Oncology Department of Jinnah Postgraduate Medical Centre, Karachi Pakistan for 1 year. Data was collected using non-probability convenient sampling technique after taking informed consent from 316 patients diagnosed as having cancer on histopathology undergoing treatment with chemotherapeutic agent and having neutropenia along with fever as a single oral temperature of $>38.3$ ${ }^{0} \mathrm{C}$. Patients who had co-morbid conditions such as diabetes heart disease or psychiatric illness were excluded from this study. The variables recorded were age, gender, chemotherapy protocol, number of days of chemotherapy, hemoglobin, total leukocyte count, neutrophils, monocytes, platelets and creatinine. Our study showed that among male and female cancer patients on chemotherapy more than half of males were found to have febrile neutropenia [26] while fewer females had febrile neutropenia. The cancer patients are most prone [27] to developing electrolyte abnormalities. This was an observational study conducted for one year in oncology ward of Jinnah Postgraduate Medical Centre, Karachi for duration of one year from April 2016 to March 2017. Single or combination chemotherapy was administered to cancer patients.

The variables included were gender, body surface area, type of cancer, chemotherapy protocol, number of days on chemotherapy, electrolyte levels before and after therapy. Furthermore, no correlation was observed in various electrolytes with the duration of chemotherapy although the difference in [27] electrolyte levels is not clinically significant and can be managed promptly in less time. The primary malignancies of the biliary tract [28] cholangiocarcinoma and gallbladder cancer often present at an advanced stage and are marginally sensitive to radiation and chemotherapy. Accumulating evidence indicates that molecularly targeted agents may provide new hope for improving treatment response in biliary tract carcinoma-BTC. Research focusing on understanding the molecular basis of biliary tumorigenesis will continue to identify for targeted therapy the key mutations that drive growth and invasion of biliary neoplasms. Additional strategies that have emerged for treating this malignant disease include targeting the [28] epigenetic alterations of BTC and immunotherapy. Our study showed that significant difference [29] exists in some of the hematological parameters including hemoglobin levels platelet count total leukocyte count neutrophil count monocyte count and absolute neutrophil count in patient treat with different chemotherapeutic drugs suffering from febrile neutropenia.

Data was collected using non-probability convenient sampling technique after taking informed consent from 318 patients diagnosed as having cancer on histopathology undergoing treatment with chemotherapeutic agent and having neutropenia along with fever as a single oral temperature of $>38.3{ }^{\circ} \mathrm{C}$. Patients who had comorbid conditions such as diabetes, heart disease, or psychiatric illness were excluded from this study. The variables recorded were age gender chemotherapy protocol number of days of chemotherapy hemoglobin, [29] total leukocyte count, neutrophils, monocytes, platelets and creatinine. This work aimed to characterize and [30] quantify the nanoscale particles emitted by a typical heavy-duty industrial photocopier and printer to assess the long-term effect of these particles on occupational health. This study also identified the settling time for the nanoscale aerosol in the work environment as twelve hours with the existing ventilation system. The potential health risk related to toner [30] particles is also explored. The prevalence of smoking chest pain vision problems fatigue and confusion were found to be different between both genders. Furthermore, the prevalence of smoking, headache, vertigo, chest pain, vision problems, dyspnea, increased urinary frequency, nausea, sleep apnea irregular [31] heartbeat/palpitation fatigue and confusion were found to be different between both age groups.

\section{Conclusion}

Due to the Advancement in Medical Sciences and Medical Treatment, Inventions people are living longer and healthier than ever before. Nuclear Radiotherapy, Nuclear radiology, MRI Scan, CT Scan, X Rays, Ultrasound, Angioplasty and Angiography others made the diagnosing and treatment easier for the patients. Current COVID-19 Pandemic, MERS, SARS, EBOLA and other epidemics teaches us the lesson than as the world population grows, we need more research and technology to handle Pandemic such as COVID-19. More resources and advance technology are needed to battle diseases and training for medical staff is needed.

\section{References}

1. Zhang R, Wang X, Ni L, Di X, Ma B, et al. (2020) COVID-19: Melatonin as a Potential Adjuvant Treatment. Life Sciences 250: 117583.

2. Ahsan Ali Siddiqui (2020) The Need of Early Detection of Positive COVID-19 Patients in the Community by Viral Tests (e.g. RTPCR Tests) and Antibody Tests (Serological Tests) to Stop the Spread. AJBSR 9(1): 78-87.

3. Abdurrahman Tufan, Aslihan Güler, Marco C (2020) COVID-19, Immune System Response, Hyperinflammation and Repurposing Antirheumatic Drugs. Turkish Journal of Medical Sciences 50(SI-1): 620-632.

4. Ahsan Ali Siddiqui (2020) COVID-19 Pandemic and Public health Preventions to Reduce the Infection, Incidence and Distribution among the Community. OAJBS 2(2): 345-352. 
5. Google How does PCR Testing for COVID-19 work (2020) Images.

6. Serap Yavuz, Serhat Ünal (2020) Antiviral Treatment of COVID-19. Turkish Journal of Medical Sciences 50(SI-1): 611-619.

7. Ahsan Ali Siddiqui (2020) Role of Convalescent Plasma Therapy in Successful Prevention and Treatment of Covid-19 Novel Corona Virus Critical Patients, In 2020 Global Pandemic. Biomed J Sci \& Tech Res 28(2): 21398-21407.

8. (2020) Google COVID-19 Cycle, COVID-19 Cycle Images.

9. Ahsan Ali Siddiqui (2020) The Urgent Need of Reliable and Approved Vaccination for COVID-19 Novel Corona Virus in Current Pandemic. Biomed J Sci \& Tech Res 28(2): 21435-21443.

10. Ahsan Ali Siddiqui (2020) The Recent Management and Treatment of COVID-19 Novel Corona Virus "Better use of Science, Better Treatment for COVID-19 Patients". OAJBS 2(3): 366-373.

11. Ahsan Ali Siddiqui (2020) The Epidemiology of COVID-19 Novel Corona Virus to Possibly Control the Disease and Other Factors Relating to Health Around the World. OAJBS 2(2): 330-337.

12. Ahsan Ali Siddiqui (2020) True or not? Chinese government quotes WHO Chief statement "that there is no Evidence that the New Coronavirus Novel COVID 19 was Produced in the Laboratory" But US Government Says, "that the Coronavirus Originated from a Laboratory in China despite the Lack of Evidence". Biomed J Sci \& Tech Res 27(5): 2114821155.

13. Sarfraz Md, Shaikh S, Zaidi SA, Raees A, Siddiqui AA, et al. (2018) Blood Pressure Levels and Urinary Frequency in Hypertensive Patients: A Cross-sectional Analysis. J Palliative Care Med 8: 345.

14. Google (2020) Hypertension risk factors.

15. Momin A, Samina B, Uzma G, Ahsan Ali S, Hanieya S, et al. (2018) Management of Dengue Infection; a Prospective Study Highlighting the Effect of Silymarin on Liver Functions Test. Palliative Med Care 5(4): 1-7.

16. Momin A, Anwar A, Imtiaz M, Mustafa N, Ahsan Siddiqui, et al. (2019) Gender and age-based evaluation of clinical signs and symptoms of dengue: A secondary data analysis. SOJ Microbiol Infect Dis 7(1): 1-4.

17. Google Dengue Hemorrhagic fever (2020) Images.

18. A Siddiqui (2018) Tuberculosis in Adults in Pakistan: Its Epidemiology, Preventive Measures and Current Legislation. Journal of American Academic Research 6(3): 33-38.

ISSN: 2574-1241

DOI: $10.26717 /$ BJSTR.2020.28.004695

Ahsan Ali Siddiqui. Biomed J Sci \& Tech Res (C) (i) This work is licensed under Creative

Submission Link: https://biomedres.us/submit-manuscript.php
19. A Siddiqui (2018) Critically Review and Evaluate National Tuberculosis Control Program (NTP) of Pakistan. Journal of American Academic Research 6(3): 28-32.

20. Google Tuberculosis (2020) Images.

21. Ahsan Ali S (2018) The Global Threat of Bird (Avian) Flu its Treatment Methods and Public Health Preventive Measures. SOJ Vet Sci 4(3): 1-4.

22. IBM (2006) IBM SPSS Software USA.

23. Jamali Z, Siddiqui AA, Jamali D, Nazim S, Hasan S, et al. (2018) Correlation of Early and Late Cord Clamping Time with Hematological Variables: An Observation Study Focusing on The Neonatal Outcomes. SOJ Gynecology Obstetric Women's Health 4(1): 1-5.

24. Amna MB, Siddiqui AA, Wajid Z, Moin A, Khan A, et al. (2018) Presentations in Patients of Chronic Myeloid Leukemia; an Observational Study Focusing on the Association of Haematological Parameter on Gender. Cancer Sci Res Open Access 5(1): 1-5.

25. Casey SC, Amedei A, Aquilano K, Azmi AS, Benencia F, et al (2015) Cancer prevention and therapy through the modulation of the tumor microenvironment. Semin Cancer Biol 35(Suppl): S199-S223.

26. Ali J, Reena K, Ahsan Ali S, Nasir M, Samurna S, et al. (2018) Febrile Neutropenia in Patients Receiving Chemotherapy; an observational study highlighting its association with haematological parameters on gender basis. Cancer Sci Res Open Access 5(1): 1-5.

27. Ahsan Ali S, Reena Kumari, Khurram Zia, Zubair T, Imtiaz S, et al. (2018) Correlation of Duration of Chemotherapy with Electrolytes in Cancer Patients: A Prospective Study Assessing the Relationship with Various Electrolytes. Cancer Sci Res Open Access 5(2): 1-4.

28. Reena Kumari, Ahsan Ali S, Shahzain H, Atika S, Sabahat N, et al. (2018) Chemotherapy in Different Cancers; an Observational Study Highlighting the Association of Febrile Neutropenia with Various Hematological Parameters. Palliative Med Care 5(3): 1-4.

29. Eric Marks, Nelson Yee (2016) Molecular genetics and targeted therapeutics in biliary tract carcinoma. World J Gastroenterol 22(4): 1335-1347.

30. Adetunji H, Pinto LM, Siddique A, Samuel S (2009) Potential occupational health risk from exposure to nano-scale particles from photocopiers - A Pilot Study. International Journal of Industrial Engineering 2(1): 15-27.

31. Hafsa K, Ahsan AS, Summaiya I, Zarghoona W, Sana N, et al. (2018) Prevalence of Clinical Signs and Symptoms of Hypertension: A Gender and Age Based Comparison. Palliative Med Care 5(2): 1-8.

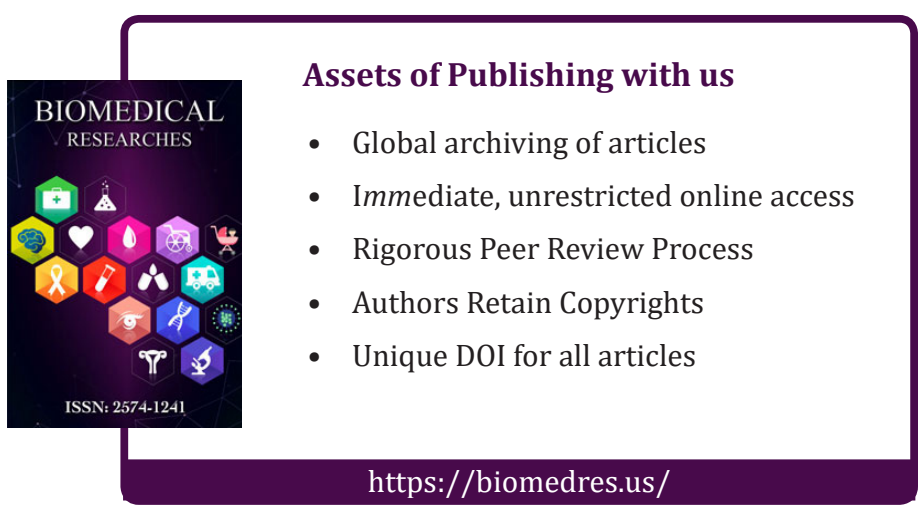

